\title{
Gradual Electronic Health Record Implementation: New Insights on Physician and Patient Adaptation
}

\author{
Renée R. Sbield, $P b D$ \\ Roberta E. Goldman, PbD \\ David A. Anthony, MD \\ Nina Wang, EdD \\ Richard J. Doyle, PbD \\ Jeffrey Borkan, $M D, P b D$
}

Department of Family Medicine, Warren Alpert Medical School of Brown University and Memorial Hospital of Rhode Island, Pawtucket, Rhode Island
Conflicts of interest: none reported

\section{CORRESPONDING AUTHOR}

Renée R. Shield, PhD

Center for Gerontology and Health Care Research

Brown University

Providence, RI 02912

Shield, Box G 121(6)

Brown University, Providence, RI 02912

renee_shield@brown.edu

\begin{abstract}
PURPOSE Although there is significant interest in implementation of electronic health records (EHRs), limited data have been published in the United States about how physicians, staff, and patients adapt to this implementation process. The purpose of this research was to examine the effects of EHR implementation, especially regarding physician-patient communication and behaviors and patients' responses.
\end{abstract}

METHODS We undertook a 22-month, triangulation design, mixed methods study of gradual EHR implementation in a residency-based family medicine outpatient center. Data collection included participant observation and time measurements of 170 clinical encounters, patient exit interviews, focus groups with nurses, nurse's aides, and office staff, and unstructured observations and interviews with nursing staff and physicians. Analysis involved iterative immersion-crystallization discussion and searches for alternate hypotheses.

RESULTS Patient trust in the physician and security in the physician-patient relationship appeared to override most patients' concerns about information technology. Overall, staff concerns about potential deleterious consequences of EHR implementation were dispelled, positive anticipated outcomes were realized, and unexpected benefits were found. Physicians appeared to become comfortable with the "third actor" in the room, and nursing and office staff resistance to EHR implementation was ameliorated with improved work efficiencies. Unexpected advantages included just-in-time improvements and decreased physician time out of the examination room.

CONCLUSIONS Strong patient trust in the physician-patient relationship was maintained and work flow improved with EHR implementation. Gradual EHR implementation may help support the development of beneficial physician and staff adaptations, while maintaining positive patient-physician relationships and fostering the sharing of medical information.

Ann Fam Med 2010;8:316-326. doi:10.1370/afm.1136.

\section{INTRODUCTION}

The electronic health record (EHR) may improve health care delivery ${ }^{1-6}$ by facilitating physician communication about medications, ${ }^{3,7}$ enhancing documentation, ${ }^{4,8,9}$ increasing efficiency, ${ }^{8-12}$ and fostering information sharing and responsibility with patients..$^{10,11}$ Implementation is often costly ${ }_{1}^{13}$ takes time and computer expertise ${ }_{1}^{14}$ and has unanticipated consequences. ${ }^{15-17}$ Concerns include its negative influence on the physicianpatient encounter ${ }^{18-20}$ altering the patient's narrative in documentation, ${ }^{21}$ reducing patient-centeredness, ${ }^{16,22-23}$ and affecting medical decision making and the physician-patient relationship. ${ }^{17,24-27}$

Even though empirical studies of the EHR have increased ${ }_{1}^{8}$ underscoring the physical room layout ${ }^{14,17-18,25}$ and how consultation computers are 
"more than just pieces of furniture,"28 few mixed methods inquiries have explored the impact of EHRs on actual clinical encounters, patients' perspectives, and physicians' adaptive strategies. Nation-specific challenges, such as fee-for-service environments, may pose barriers to EHR implementation. ${ }^{14,29}$ A Kuwaiti example reports the experiences of clerical staff regarding EHR implementation. ${ }^{30}$ Although the impact of EHRs on physician-patient communication is controversial, more investigation is needed that compares EHR with non-EHR environments. ${ }^{8}$ Finally, longitudinal and holistic approaches to this subject are rare.

We report the perspectives and behaviors of staff, physicians, and patients elicited during a long-term, mixed methods study undertaken in a residency-based family medicine outpatient clinic. Specifically, we examined the effects of gradual EHR implementation on the clinical encounter and its milieu.

\section{METHODS}

Our triangulation design, mixed methods study ${ }^{31}$ examined how computerization affected physician behaviors, physician-patient interactions, and patient perceptions of physician behaviors throughout EHR implementation. Table 1 displays the quantitative and qualitative methods used.

Methods included participant observation of physician-patient clinical encounters and exit interviews with patients; brief conversations and observations with nurses, nurse's aides (certified nursing assistants),

Table 1. Methods Used and Outcomes Observed in Phases of Study

\begin{tabular}{|c|c|c|c|}
\hline & $\begin{array}{l}\text { Before } \\
\text { Implementation }\end{array}$ & Transition $^{b}$ & $\begin{array}{l}\text { After } \\
\text { Implementationc }\end{array}$ \\
\hline \multirow[t]{6}{*}{ Methods } & $\begin{array}{l}\text { Consultation } \\
\text { observations }\end{array}$ & $\begin{array}{l}\text { Consultation } \\
\text { observations }\end{array}$ & $\begin{array}{l}\text { Consultation } \\
\text { observations }\end{array}$ \\
\hline & Patient interviews & Patient interviews & Patient interviews \\
\hline & $\begin{array}{l}\text { Timed-tasks } \\
\text { measurements }\end{array}$ & $\begin{array}{l}\text { Timed-tasks } \\
\text { measurements }\end{array}$ & $\begin{array}{l}\text { Timed-tasks } \\
\text { measurements }\end{array}$ \\
\hline & Other observations ${ }^{d}$ & Other observations ${ }^{d}$ & Other observations $^{d}$ \\
\hline & Staff focus groups & - & Staff focus groups \\
\hline & Physician Interviews & - & Physician Interviews ${ }^{e}$ \\
\hline \multirow[t]{5}{*}{ Outcomes } & Use of patient chart & Use of patient chart & Use of patient chart \\
\hline & Use of EHR & Use of EHR & Use of EHR \\
\hline & Time in and out of office & Time in and out of office & Time in and out of office \\
\hline & $\begin{array}{l}\text { Physician body position/ } \\
\text { verbal strategies }\end{array}$ & $\begin{array}{l}\text { Physician body position/ } \\
\text { verbal strategies }\end{array}$ & $\begin{array}{l}\text { Physician body position/ } \\
\text { verbal strategies }\end{array}$ \\
\hline & Patient/staff satisfaction & Patient/staff satisfaction & Patient/staff satisfaction \\
\hline
\end{tabular}

EHR = electronic health record.

a January-May 2005.

b June 2005-March 2006

' Residents, April-June 2006; faculty, April-November 2006.

${ }^{d}$ Observations and conversations with nursing staff, clerical staff and physicians at nurses' stations.

e Extensive physician interview data to be reported at a later date. and physicians at the nurses' stations; and focus groups with front-office staff, nurses, and nurse's aides. Two visual analog scales (VAS) were used to record the observer's perception of how the documentation method structured the session and its overall role in the encounter. A stopwatch was used to time events in the chronology of the consultation. Extensive interviews with the physicians before and after implementation were also conducted and will be published separately. Institutional review board approval from Memorial Hospital of Rhode Island was formally granted; study participants signed a written consent and received no incentive or compensation.

\section{Study Setting and Participants}

From January 2005 through November 2006, a team anthropologist (R.R.S.) observed clinical encounters and conducted patient interviews at the Family Care Center at Memorial Hospital of Rhode Island, a teaching hospital affiliated with the Warren Alpert Medical School of Brown University; another (R.E.G.) conducted focus groups. In the 5 -month period preceding installment of computers in the patient examination rooms (the preimplementation period), 10 to $12 \mathrm{com}$ puters were available in common work areas. During the 10 -month transition period, computers were gradually installed in all 27 examination rooms and nurses' workstations. Physicians documented their consultations in the paper chart or typed directly into the EHR. Nurses inputted blood pressure, temperature, pulse rate, weights, and other data before the physi-

cian entered the consultation room, using the paper chart before EHR implementation, using both the chart and the EHR during the transition, and using the consultation room computer after full EHR implementation. The period after implementation lasted 3 months for third-year residents (until they graduated from the residency); this phase extended to 6 months for faculty members to ensure an equal number of consultation visits. When computers were fully installed, physicians documented their consultations using the EHR only. Some physicians completed the consultation documentation by visit's end, whereas others did not. 


\section{Data Collection}

Physician participants included family medicine faculty (excluding coauthors) and second-year residents (continuing through their third year). Patient encounters were observed during clinic sessions. Patients of participating physicians were purposively sampled to maintain a similar number of patients per physician per study phase. Inclusion criteria for patients included Englishspeaking individuals, age 18 years or older, and a visit for an acute problem or follow-up (excluding intimate physical examinations). The clinic used Centricity (formerly called Logician), a widely utilized primary care EHR system. A separate intrainstitutional software program was available on all computers for laboratory, imaging transcription, pathology, and demographic registration reports. With the exception of 2 rooms with notebook computers, all rooms became equipped with a desktop computer with a 15 -inch flat-screen monitor.

The researcher observing the clinical encounters alternated among the 3 nurses' stations in recruiting patients. While taking an eligible patient's temperature and blood pressure, the nurse's aide introduced the study and asked whether the researcher might elaborate. If the patient agreed, the researcher explained the study and then obtained informed consent if the patient was willing. She returned with the physician to sit or stand silently during the consultation with a stopwatch, using a study protocol (Supplemental Appendix

1 , available online at http://www.annfammed.

in org/cgi/content/full/8/4/316/DC1) to describe and

time activities. She documented patients' reasons for refusal and noted EHR-relevant observations and informal conversations at the nurses' stations.

The protocol noted chronology, eye contact, physician-patient communication style, physician exits, and participants' behaviors. The researcher recorded her perception of how much the documentation system (1) structured the visit and (2) played a role in the visit on each 10-cm VAS. Zero centimeters indicated minimal structuring or role, and $10-\mathrm{cm}$ indicated maximal structuring or role.

After the consultation, the researcher conducted a brief, tape-recorded, qualitative interview with the patient, eliciting the patient's perceptions of the physician's documentation, communication, and quality of the encounter (Supplemental Appendix 2, available

सim online at http://www.annfammed.org/cgi/content/ full/8/4/316/DC1). Interviews were transcribed.

The researcher typed notes from each protocol within 24 hours to preserve impressions. Data were collected until saturation in all domains of observation was achieved (eg, the use of documentation in each phase by each physician). ${ }^{32}$ Handwritten nursing station observations of physicians' and other staff interac- tions regarding the mechanics of documentation were also recorded in a notebook.

\section{Focus Groups with Clinic Staff}

Before implementation we held 3 focus groups with clinic nurses, nurse's aides, and clerical staff, we held 2 focus groups after implementation. Moderated by a coauthor (R.E.G.), each focus group session lasted approximately 1 hour, was tape-recorded, and professionally transcribed.

\section{Data Analysis}

We used immersion/crystallization and other accepted methods for analysis of the data from each phase. ${ }^{32-34}$ The multidisciplinary analysis team included 2 practicing family medicine faculty, 1 physician (D.A.) and 1 physician-anthropologist (J.B.) who were both early adopters of EHR 2 anthropologist faculty (R.R.S. and R.E.G.); and 2 additional researchers who conducted physician interviews (N.W. and R.D.). Regular, extensive analysis meetings were held to discuss observation logs and transcripts from the patients' interviews and focus group sessions, and to iteratively consider confirming and discrepant interpretations of data until reconciliation. ${ }^{32}$ Observations and patient interview transcripts with sample quotes were abstracted by several team members onto a spreadsheet to compare cases.

In analyzing the quantitative data, visits were categorized as paper chart or EHR for the primary charting method. Total time for activities (eg, time spent out of the room) was compared among categories using 2 -sided $t$ tests. VAS scales scores were measured in millimeters and compared using $t$ tests.

\section{RESULTS}

During the study 13 faculty physicians and 13 residents participated in 170 observed clinical encounters. Approximately 170 hours of participant observation also occurred at the nurses' stations. Each physician was observed during 4 to 9 patient encounters (faculty average 5.9; resident average 7.3) during the 3 study phases. Table 2 displays observations of faculty and residents in each phase of EHR implementation. Twenty Family Care Center staff participated in focus groups.

Approximately one-half of the patients approached consented to participate in the study. Reasons for refusal included not having enough time, feeling unwell, wanting privacy with the physician, and being uninterested in participating. Table 3 displays patient demographic characteristics.

\section{Before Implementation (January-May, 2005)}

In this phase, only problem and medication lists were recorded in the EHR. The hospital laboratory software 


\begin{tabular}{|c|c|c|c|}
\hline Physicians & $\begin{array}{c}\text { Before } \\
\text { Implementation }^{\text {a }}\end{array}$ & Transition $^{b}$ & $\begin{array}{c}\text { After } \\
\text { Implementationc }\end{array}$ \\
\hline Faculty $(n=13)$ & 17 & 32 & 26 \\
\hline Residents ( $n=13$ ) & 21 & 39 & 35 \\
\hline Total $(n=26)$ & 38 & 71 & 61 \\
\hline \multicolumn{4}{|c|}{$\begin{array}{l}\text { January-May } 2005 . \\
\text { J June 2005-March } 2006 \\
\text { ' Residents: April-June 2006, faculty: April-November } 2006\end{array}$} \\
\hline
\end{tabular}

\begin{tabular}{|c|c|c|}
\hline Characteristic & $\%$ Male $^{a}$ & $\%$ Female $^{b}$ \\
\hline \multicolumn{3}{|l|}{ Age, y } \\
\hline $17-35$ & 17.4 & 42.2 \\
\hline $36-65$ & 58.6 & 46.2 \\
\hline $65+$ & 21.7 & 9.1 \\
\hline Missing & 2.2 & 2.5 \\
\hline \multicolumn{3}{|l|}{ Self-identified ethnicity } \\
\hline White or European American & 71.7 & 67.8 \\
\hline African American or Hispanic & 13.1 & 16.5 \\
\hline $\begin{array}{l}\text { Other (Middle Eastern, Cape } \\
\text { Verdean, American Indian) }\end{array}$ & 8.7 & 5.0 \\
\hline Missing or refused to answer & 6.5 & 10.7 \\
\hline \multicolumn{3}{|l|}{ Education level } \\
\hline$<$ High school degree & 34.8 & 29.8 \\
\hline High school degree or GED & 30.4 & 25.6 \\
\hline Some college or above & 30.5 & 41.3 \\
\hline Missing & 4.3 & 3.3 \\
\hline \multicolumn{3}{|l|}{ Computer experience } \\
\hline None or little & 52.2 & 34.7 \\
\hline Some or much & 47.8 & 63.6 \\
\hline Missing & 0.0 & 1.7 \\
\hline \multicolumn{3}{|l|}{ Computer access } \\
\hline None or little & 47.9 & 37.2 \\
\hline Some or much & 50.0 & 61.1 \\
\hline Missing & 2.2 & 1.7 \\
\hline \multicolumn{3}{|l|}{$\mathrm{GED}=$ general equivalency degree. } \\
\hline \multicolumn{3}{|c|}{ Note: Of the 170 patients, 3 files were missing. } \\
\hline \multicolumn{3}{|l|}{$\mathrm{a} n=46(27 \%)$} \\
\hline
\end{tabular}

was used for laboratory data without communication between systems. Except for 2 early adopters who used a laptop computer during consultations, other physicians recorded patient histories in the paper chart. Physicians frequently left the consultation rooms for laboratory and test results and to update clinical lists and prescriptions. Sitting facing the patient, physicians usually placed the paper chart on their laps to read and record notessome looking at patient, others at chart, some silent, and others reading aloud while writing. Although observed physician eye contact with patients varied, patients generally expressed satisfaction in exit interviews.

\section{Patients' Views}

Patients indicated varying levels of awareness of EHR implementation. In response to whether they thought their health information was stored on the computer, this comment was not unusual: "I have no idea; I would think so, probably." Illustrative patient quotes are included in Table 4.

Patient interview responses generally reflected approval of either documentation method, though some voiced criticism of the EHR. Patients often recalled more eye contact and less chart-writing than was observed by the researcher. One patient noted, however, "I'd rather see them writing something down than just listening." Another criticized: "She was writing what she was saying, not what I was saying..." Patients stated that the EHR improved physicians' work, legibility, information storage and retrieval, confidentiality, accuracy, and communication among physicians, and it reduced physicians' exits from the room. One man said: "...a computer is such an added benefit because you can immediately pull information."

Although patients were often neutral about EHR use, some noted the potential for hacking, lost records, confidentiality breaches, technological malfunction, and viruses. One 70-year-old man claimed, "It all depends who it's made available to afterwards... it makes me concerned that other people can get into your records."

\section{Clinical and Clerical Staff Views}

During the focus group sessions staff anticipated greater legibility, more accuracy, no filing, and fewer missing charts, with one saying the EHR "...will free up a lot of the girls from finding the charts which are always missing," but predicting doctors as "barriers." They were pleasantly surprised by ease of referrals: "Everybody was nervous... .but then when we started doing it, we all loved it." Nurse's aides worried about their inadequate typing abilities and children's potential destructiveness. Nurses feared short-term double work. One said, "We'll always have the record though. And we will no longer have to worry, you know, they can't find it...." Table 5 lists additional staff comments from focus groups.

\section{Transition}

During transition, computers were gradually installed in consultation rooms. Nurses entered clinical intake information in the paper and electronic records. EHR capabilities included progress notes. Physicians typed notes in the EHR, printed them for the paper chart, or continued writing them by hand. Occasional mishap and charting redundancy increased staff workload $;$ a 
Table 4. Sample Patient Quotes Related to EHR Implementation

\begin{tabular}{|c|c|c|c|}
\hline $\begin{array}{l}\text { Patient } \\
\text { Variable }\end{array}$ & Before Implementation & Transition & After Implementation \\
\hline $\begin{array}{c}\text { Aware of } \\
\text { EHR }\end{array}$ & $\begin{array}{l}\text { I guess so, yeah (female, } 65 \text { y, } \\
\text { some CE) } \\
\text { Yes, at the nurses' station (female, } \\
24 \text { y, extensive CE) }\end{array}$ & $\begin{array}{l}\text { I hope so. My information should be in } \\
\text { the computer (male, } 32 \text { y, no CE) } \\
\text { She does it on the computer... She puts } \\
\text { everything right on the computer } \\
\text { when we're talking (female, } 46 \mathrm{y} \text {, } \\
\text { extensive CE) } \\
\text { Yes he is (male, } 45 \mathrm{y} \text {, no CE) } \\
\text { We're in the } 21 \text { st century. Sooner or } \\
\text { later that paperwork is going to disap- } \\
\text { pear, you know? (male, } 46 \text { y, some CE) }\end{array}$ & NA \\
\hline $\begin{array}{l}\text { Not aware } \\
\text { of EHR }\end{array}$ & $\begin{array}{l}\text { Not that I know of; is it that little } \\
\text { pocket thing [PDA]? (female, } 49 \\
\text { y, extensive CE) } \\
\text { I have no idea; I would think so, } \\
\text { probably (male, } 45 \text { y, little CE) }\end{array}$ & $\begin{array}{l}\text { I would probably say no (female, } 25 \text { y, } \\
\text { some CE) } \\
\text { I have no idea (female, } 18 \text { y, little CE) }\end{array}$ & NA \\
\hline $\begin{array}{l}\text { General } \\
\text { reactions } \\
\text { to writing } \\
\text { and/or } \\
\text { EHR }\end{array}$ & $\begin{array}{l}\text { I'd rather see them writing some- } \\
\text { thing down than just listening... } \\
\text { and not writing anything down } \\
\text { (male, } 41 \text { y, some CE) } \\
\text { She's putting down what I'm telling } \\
\text { her...everybody forgets things. So } \\
\text { that way there, you put it down } \\
\text { on paper, and you know, you } \\
\text { don't forget it. You can refer back } \\
\text { to it. That's why it don't bother } \\
\text { me at all (male, } 70 \text { y, some CE) } \\
\text { She was writing what she was say- } \\
\text { ing, not what I was saying.... I } \\
\text { didn't like what she was writing } \\
\text { (female, about } 45 \text { y, extensive CE) }\end{array}$ & $\begin{array}{l}\text { The first day when he came with that } \\
\text { [computer], you know, I didn't say } \\
\text { nothing. I think he knows what he's } \\
\text { doing.... To me, it was the same } \\
\text { (female, } 80 \text { y, no CE) } \\
\text { She was writing down what my concerns } \\
\text { were-I mean what her concerns were } \\
\text { because she knows me... Well, I think } \\
\text { everything is going computer any- } \\
\text { way.... The computer is fine (female, } \\
59 \text { y, little CE) } \\
\text { She does it on the computer.... She puts } \\
\text { everything right on the computer } \\
\text { when we're talking... [typing is]...like } \\
\text { a second nature thing.... Even when } \\
\text { she's putting things on the computer, } \\
\text { I still feel like she's paying attention to } \\
\text { me (female, } 46 \text { y, extensive CE) }\end{array}$ & $\begin{array}{l}\text { It seemed like it would be easier to look up } \\
\text { when she looks at my cholesterol level, } \\
\text { you know, click on the computer-last } \\
\text { cholesterol level.... It didn't make me feel } \\
\text { like she was spending her time typing, so } \\
\text { it didn't feel like she was taken away by, } \\
\text { "Hold on, I've got to type this." She just } \\
\text { did it. So I didn't even realize (female, } \\
46 \text { y, extensive CE) }\end{array}$ \\
\hline $\begin{array}{l}\text { Positive } \\
\text { reactions } \\
\text { to EHR }\end{array}$ & $\begin{array}{l}\text { [EHR helps] access the information } \\
\text { a lot faster (female, } 34 \text { y, no CE) } \\
\text { Obviously to me a computer is such } \\
\text { an added benefit because you } \\
\text { can immediately pull information } \\
\text { (male, } 54 \text { y, extensive CE) } \\
\text { They can pull it [the record] up eas- } \\
\text { ier (female, about } 22 \text { y, little CE) } \\
\text { I think it's useful for them to have } \\
\text { computers...so they don't have } \\
\text { to keep writing everything down } \\
\text { (female, } 18 \text { y, some CE) } \\
\text { [EHR is] a lot easier instead of hav- } \\
\text { ing to look through charts all the } \\
\text { time... and maybe visits would } \\
\text { go even quicker (female, } 26 \text { y, } \\
\text { extensive CE) }\end{array}$ & $\begin{array}{l}\text {...they could pull the record up quicker } \\
\text { (male, } 26 \text { y, extensive CE) } \\
\text { It's better for them. They can just get } \\
\text { it that way without looking for files } \\
\text { (female, } 55 \text { y, little CE) } \\
\text { I rather have that [EHR] so that if I } \\
\text { had to go to the emergency room, } \\
\text { and they asked me things I wouldn't } \\
\text { know, I would say, go look it up, and } \\
\text { everything would be there (female, } \\
18 \text { y, no CE) } \\
\text { There ought to be less of a mound in } \\
\text { [the landfill] someday... I trust them } \\
\text { [PCPs] thoroughly (female, } 57 \text { y, } \\
\text { extensive CE) } \\
\text { If you're visiting in New Hampshire, } \\
\text { bingo, [you can get your records/ } \\
\text { health information] over the computer } \\
\text {... think [it] is wise (female, } 55 \text { y, } \\
\text { little CE) }\end{array}$ & $\begin{array}{l}\text { I don't mind [the information in the com- } \\
\text { puter] because they must have a system } \\
\text { maybe to protect all the information.... } \\
\text { It's a good thing because like I say, you } \\
\text { don't have to go looking through the } \\
\text { books. You bring everything up (male, } \\
83 \text { y, no CE) } \\
\text { It remembers more, never forgets like } \\
\text { people do, and paper can get lost (male, } \\
53 \text { y, unknown CE) } \\
\text { [The] visit was smoother [with the EHR] } \\
\text { (female, } 35 \text { y, extensive CE) } \\
\text { Paperwork is out of style, and I believe the } \\
\text { computers will be something for the world's } \\
\text { future.... It's necessary.... Why should I } \\
\text { worry about it? I'm not telling him lies. I'm } \\
\text { just telling him I'm sick, and I see a doc- } \\
\text { tor.... So I'm not worried about whatever is } \\
\text { in the computer.... I'm not a doctor, and I } \\
\text { came here because I trust the doctor. And } \\
\text { that's enough for me. Whatever he puts in } \\
\text { there is part of his job (male, } 65 \text { y, no CE) } \\
\text { The flow doesn't change when she's talking } \\
\text { to me..., so like I know she's taking notes, } \\
\text { but I don't really pay that much attention } \\
\text { I guess because I'm used to it (female, } \\
31 \text { y, extensive CE) } \\
\text { Oh, that doesn't bother me no more than } \\
\text { really having your medical record out on } \\
\text { the counter. I just think that it's faster, so } \\
\text { she has more time to talk to me (informa- } \\
\text { tion not available) } \\
\text { I trust her [PCP]...anything I need to know } \\
\text { she tells me about me. I mean she doesn't } \\
\text { hide anything from me (female, } 56 \text { y, } \\
\text { unknown CE) }\end{array}$ \\
\hline
\end{tabular}




\begin{tabular}{|c|c|c|c|}
\hline $\begin{array}{l}\text { Patient } \\
\text { Variable }\end{array}$ & Before Implementation & Transition & After Implementation \\
\hline \multirow[t]{5}{*}{$\begin{array}{l}\text { Concerns } \\
\text { about } \\
\text { EHR }\end{array}$} & \multirow{2}{*}{$\begin{array}{l}\text { It all depends who it's made avail- } \\
\text { able to afterwards. You know } \\
\text { we're going through a period } \\
\text { right now with the government. } \\
\text { This here government type thing } \\
\text { is really crazy, excuse me, with } \\
\text { records and everything. And } \\
\text { it makes me concerned that } \\
\text { other people can get into your } \\
\text { records... (male, } 70 \text { y, some CE) }\end{array}$} & $\begin{array}{l}\text {... people can take information and } \\
\text { everything... [the] computer is another } \\
\text { enemy...they can steal all the informa- } \\
\text { tion from you (male, } 32 \text { y, no CE) }\end{array}$ & $\begin{array}{l}\text { I just don't want my medical records being } \\
\text { opened up on the computer for the world } \\
\text { to see.... Personally I would prefer the } \\
\text { paper chart (female, } 34 \mathrm{y} \text {, little (E) }\end{array}$ \\
\hline & & \multirow[t]{4}{*}{$\begin{array}{l}\text { I'm fine just as long as nobody else } \\
\text { gets them besides doctors to know } \\
\text { my information (female, } 32 \text { y, exten- } \\
\text { sive CE) }\end{array}$} & $\begin{array}{l}\text { [EHR is] OK as long as no one breaks in and } \\
\text { gets med info. If it's easier for docs to pull } \\
\text { up info they need, OK. Better than search- } \\
\text { ing through paper records. [Preferred } \\
\text { paper to EHR] (female, } 29 \mathrm{y} \text {, extensive CE) }\end{array}$ \\
\hline & $\begin{array}{l}\text { [Hacking] could happen, you know, } \\
\text { I'm sure. I mean there's a lot of } \\
\text { hackers out there. So anything can } \\
\text { happen (male, } 36 \text { y, extensive CE) }\end{array}$ & & $\begin{array}{l}\text { Because if something goes wrong, anybody } \\
\text { can get our information off of a computer. } \\
\text { Like with the VA guys and stuff. Their data } \\
\text { might have gotten stolen (female, } 58 \mathrm{y} \text {, } \\
\text { little CE) }\end{array}$ \\
\hline & $\begin{array}{l}\text { I'm pretty sure the hospital has } \\
\text { many things to make it so people } \\
\text { can't get at it unless it's the right } \\
\text { person (male, } 45 \text { y, no CE) }\end{array}$ & & $\begin{array}{l}\text { Anybody could get to those records. The } \\
\text { point is I don't particularly care (informa- } \\
\text { tion not available). }\end{array}$ \\
\hline & $\begin{array}{l}\text { Sometimes it's OK. Sometimes it's } \\
\text { not because, you know, now we } \\
\text { can break into the computers } \\
\text { (female, } 31 \text { y, some CE) }\end{array}$ & & \\
\hline
\end{tabular}

physician was observed waiting until the nurse closed the record to input information; another day, a laptop caught fire. Clinical staff varied in their EHR styles and abilities; differences by sex, age, or profession were not discerned.

Nurses described incomplete documentation and double entry during EHR transition as: ". . .having one foot in and one foot out... medication... wasn't documented in the computer because... somebody didn't have time, or somebody didn't know how." They worried about eye contact ("... is the doctor actually going to physically touch the patient or look at the patient anymore?"), the consequences of patients viewing their chart ("...is that really a good thing... [writing] patient is noncompliant because they're...mildly obese?"), confidentiality ("Who's the father of my baby? Who's going to get that information?"), and computer crashes. They applauded saving time, patient accountability, and just-in-time EHR reminders: "'Oop, this person never had another Pap smear...' I just type out a letter and off it goes." Such comments were abundant at the nurses' stations, as when a physician noted discomfort about documenting a patient's problems within the patient's view.

\section{Patients' Views}

Table 4 reflects widespread but inconsistent patient awareness of the EHR. Some patients still replied, "I have no idea," about electronic records, even when the physicians had used the computer in their presence. As did staff members, patients expressed positive per- ceptions about speed and access and concerns about security. Some patients were more computer savvy than the health care personnel. Some patients indicated neutrality whether documentation was electronic or written. One said, "To me, it was the same" (80-yearold woman); another noted, "Well, I think everything is going computer anyway...fine" (59-year-old woman); and another said, "Even when she's putting things on the computer, I still feel like she's paying attention to me" (46-year-old woman). Staff "could pull the record up quicker" (26-year-old man); "I would say, go look it up, and everything would be there..." (18-year-old woman); and paper waste would be reduced (57-year-old woman). She added, "I trust [the physicians] thoroughly."

Patients were also concerned about security, regardless of personal computer experience. One man wanted file protection because the "computer is another enemy...they can steal all the information," whereas a 32-year-old woman said, "I'm fine just as long as nobody else gets [the files] besides doctors."

\section{Full Implementation}

With full implementation all consultation rooms were equipped with computers linked to the hospital's intranet and the Internet, and double-entry documentation was eliminated. New patient information and progress notes were inputted electronically, though physicians still examined paper charts for histories and consultation letters, and the charts often accompanied the physicians into the examination rooms. Additional EHR templates were now available for well- 
Table 5. Perceived Benefits and Challenges in Implementing an EHR from Clerical and Nursing Staff Focus Groups

\begin{tabular}{|c|c|c|}
\hline Variable & Perceived Benefits & Perceived Challenges \\
\hline $\begin{array}{l}\text { Physician } \\
\text { documentation }\end{array}$ & $\begin{array}{l}\text { I think if they have the computer in there, they'll docu- } \\
\text { ment better (clerical staff, before implementation and } \\
\text { during transition) } \\
\text { [Some doctors] do their notes electronically. And then } \\
\text { they print them off for me (clerical staff, before } \\
\text { implementation and during transition) } \\
\text { Some [physicians] will be very, very good (nurses, } \\
\text { before implementation and during transition) } \\
\text { [Doctors' notes] are more accurate now. Plus I think } \\
\text { your notes are done more in real time now... before } \\
\text { they used to hold onto charts forever (nurses/clerical, } \\
\text { after implementation) } \\
\text { So if they want me to do refills, then I send them } \\
\text { notes. If you don't close your chart and finish your } \\
\text { chart, I cannot update your med list, and hello, I } \\
\text { can't help you. So I think that's helped too (nurses/ } \\
\text { clerical, after implementation) }\end{array}$ & $\begin{array}{l}\text { The doctors are going to be the barriers (clerical staff, before } \\
\text { implementation and during transition) } \\
\text { They don't like transitions. Some of them don't like change. } \\
\text { They like to keep that piece of paper (clerical staff, before } \\
\text { implementation and during transition) } \\
\text { They're more comfortable writing instead of typing (clerical } \\
\text { staff, before implementation and during transition) } \\
\text { The older ones [physicians], forget it (clerical staff, before imple- } \\
\text { mentation and during transition) } \\
\text { Some... [like to] just flip through the pages [of the paper chart] } \\
\text { and get what they want, you know? (clerical staff, before } \\
\text { implementation and during transition) } \\
\text { You'll just have to pray they do it. Some are doing it [using the } \\
\text { computer] more than others (nurses, before implementation } \\
\text { and during transition) } \\
\text { Right now having one foot in and one foot out, how many } \\
\text { times do we look in the chart and say...[a medication] wasn't } \\
\text { documented in the computer because...somebody didn't have } \\
\text { time, or somebody didn't know how to do it (nurses, before } \\
\text { implementation and during transition) } \\
\text { And some [physicians] will be very, very bad (nurses, before } \\
\text { implementation and during transition) } \\
\text { And the very, very bad ones are going to have to get very, very } \\
\text { good real quick (nurses, before implementation and during } \\
\text { transition) } \\
\text { If [physicians] are in the chart and they haven't finished their } \\
\text { note, I can't update their med list (nurses/clerical, after } \\
\text { implementation) }\end{array}$ \\
\hline
\end{tabular}

Work flow You spend so much time [now] splitting charts and repairing charts, getting them together, filing them, trying to find room for them (clerical staff, before implementation and during transition)

Everybody was nervous about [the EHR for referrals] but then when we started doing it, we all loved it (clerical staff, before implementation and during transition)

Once you start doing [computer referrals], it just gets easier as you do it (clerical staff, before implementation and during transition)

It will free up a lot of the girls from finding the charts which are always missing...it's always right there on the computer (nurse's aides, before implementation and during transition)

I think they [the patients] might like it... because if...they can't find the chart, they complain... (nurse's aides, before implementation and during transition)

It's more accessible for the secretary (nurse's aides, before implementation and during transition)

We'll always have the record....and we will no longer have to worry...they can't find it or people taking it out... (nurses, before implementation and during transition)

I can just go into the EMR and say, "Oop, this person never had another pap smear"... and I just type out a letter and off it goes (nurses, before implementation and during transition)

I don't have to pull charts anymore. I used to pull about a hundred charts at a time, review the chart, send out letters, track them every month. And now I can do it all by Logician. I'm one of the non believers that turned to a believer (nurses, before implementation and during transition)

Now I can do it [input data] in between patients because I don't have to worry about going and pulling charts, getting the charts back to medical records one more time that the chart could be lost because I may have kept them in my spot for days, you know? So it's been working out really good for me (nurses, before implementation and during transition)
With slow laptops....write the vitals on scraps of paper... (nurses/ clerical, after implementation)

The only thing is when the computer goes down (nurses/clerical, after implementation)

[Double entry] labs in the computer and lab slips in docs' boxes, which then have to be filed in the chart. Also have to file MRIs and x-rays. Double the work (nurses/clerical, after implementation) 


\begin{tabular}{|c|c|c|}
\hline Variable & Perceived Benefits & Perceived Challenges \\
\hline Work flow & $\begin{array}{l}\text { It's going to save hours in the day, hours (nurses, } \\
\text { before implementation and during transition phases) } \\
\text { There are fewer missing charts. Referrals it's great } \\
\text { for. It saves a lot of time. [Physician notes are] more } \\
\text { legible. That's a major thing (nurses/clerical, after } \\
\text { implementation) } \\
\text { I personally think it's wonderful. I think it's a quick } \\
\text { flow. We can get them [patients] right in [the rooms] } \\
\text { (nurses/clerical, after implementation) } \\
\text { [for legal correspondence] Oh my gosh, all I have to do } \\
\text { is print everything up.... You can fax it, send it, what- } \\
\text { ever (nurses/clerical, after implementation) }\end{array}$ & \\
\hline $\begin{array}{l}\text { Patient safetyl } \\
\text { confiden- } \\
\text { tialityl } \\
\text { transparency }\end{array}$ & $\begin{array}{l}\text { It will definitely make all of us more accountable if the } \\
\text { patient has access to their records (nurses, before } \\
\text { implementation and during transition) } \\
\text { I think patients are going to become more knowledge- } \\
\text { able (nurses, before implementation and during } \\
\text { transition) } \\
\text { It makes a patient responsible for knowing what their } \\
\text { medications [and other medical concerns] are (nurses/ } \\
\text { clerical, after implementation) } \\
\text { I think having our patients being curious about what's } \\
\text { in their chart and what's going on about them -it's } \\
\text { good. A lot of the doctors are printing off their last } \\
\text { note and giving it to the patient...and it makes...them } \\
\text { responsible (nurses/clerical, after implementation) } \\
\text { I had patients that are forging prescriptions, and so I } \\
\text { write that in the computer.... The doctor knows it. And } \\
\text { I tell the patient. You know, we know that your phar- } \\
\text { macy called us, and you have copied prescriptions. } \\
\text { That's a felony... (nurses/clerical, after implementation) } \\
\text { I think parents looking at the computer is a great thing } \\
\text { (nurses/clerical, after implementation) }\end{array}$ & $\begin{array}{l}\text { But is that [patient access to their EHR] really a good thing? I } \\
\text { mean you know when they put like a patient is noncompli- } \\
\text { ant...or mildly obese (nurses, before implementation and } \\
\text { during transition) } \\
\text { You're asking me if I'm using drugs, and where are you putting } \\
\text { this information? I mean where is it going? Who can see it? } \\
\text { Who's the father of my baby? Who's going to get that informa- } \\
\text { tion? (nurses, before implementation and during transition) } \\
\text { My only concern is confidentiality issues (nurse's aides, before } \\
\text { implementation and during transition) } \\
\text { You have to sign into it and sign out...because you don't want to } \\
\text { leave a chart open in there and anybody can go into the chart... } \\
\text { (nurse's aides, before implementation and during transition) } \\
\text { I would think people [patients] would wonder who's going to } \\
\text { have access to this in the hospital... (nurses, before implemen- } \\
\text { tation and during transition phases) } \\
\text { I have reservations about [putting in patient information].... } \\
\text { Like when they put in things about, you know, seeking drugs } \\
\text { or... (nurses/clerical, after implementation) } \\
\text { It's fine [looking at the computer] if it's their own chart (nurses/ } \\
\text { clerical, after implementation) }\end{array}$ \\
\hline Relationship & & $\begin{array}{l}\text { I'm afraid that when the computer is in the room, the doctor } \\
\text { is going to be asking questions and just typing whatever the } \\
\text { patient says. And is the doctor actually going to physically } \\
\text { touch the patient or look at the patient anymore? (nurses, } \\
\text { before implementation and during transition) }\end{array}$ \\
\hline Other & $\begin{array}{l}\text { We're not breaking computers. We're not losing key- } \\
\text { boards (nurses/clerical, after implementation) } \\
\text { I think it's a great thing that they're going in there to do } \\
\text { something. They should put something educational on } \\
\text { there for them (nurses/clerical, after implementation) }\end{array}$ & $\begin{array}{l}\text { We find kids on the Internet all the time (nurses/clerical, after } \\
\text { implementation) } \\
\text { We tell them to get off, but the parents just allow them to get } \\
\text { on the computer, and we have many adults we find on the } \\
\text { computers (nurses/clerical, after implementation) }\end{array}$ \\
\hline
\end{tabular}

child examinations, prenatal visits, and complete physical examinations. Clinical staff still varied in their abilities and comfort when working with the EHR. Physicians often used the computer for referrals and just-intime information (examples include birth control information, toxicity of a rash cream, a pain medication).

\section{Stopwatch Measurements}

Table 6 shows that physician exits to retrieve information took less time (an average of 3.2 minutes compared with 5.9 minutes before implementa-
Table 6. Stopwatch Measurements Before and After Implementation of EHR

\begin{tabular}{lccc}
\hline Variable & $\begin{array}{c}\text { Paper } \\
\text { Before (After) }\end{array}$ & $\begin{array}{c}\text { Computer } \\
\text { Before (After) }\end{array}$ & $\begin{array}{c}\text { P } \\
\text { Value }\end{array}$ \\
\hline Total time, min & $25.6(14.9)$ & $23.8(14.4)$ & .45 \\
Time spent out of room, min & $5.9(7.0)$ & $3.2(5.0)$ & .01 \\
Physician left the room,\% & 53.5 & 59.7 & .44 \\
$\begin{array}{l}\text { Time spent on computer/ looking } \\
\quad \text { or writing in chart, min }\end{array}$ & $2.8(3.4)$ & $4.4(3.0)$ & .002 \\
$\begin{array}{l}\text { Physician talks while taking notes, \% } \\
\text { Structuring of visit by documentation } \\
\quad \text { system (VAS) }\end{array}$ & 92 & 97 & .21 \\
$\begin{array}{l}\text { Role of the documentation system } \\
\text { (VAS) }\end{array}$ & $21.5(19.3)$ & $33.8(22.8)$ & .001 \\
\hline EHR = electronic health record; VAS = visual analog scale. & & \\
\hline
\end{tabular}


tion, $P \leq .01$ ), and patients seemed to understand their records were maintained in the EHR. Though physicians stated concerns about losing eye contact with patients when using the EHR, and stopwatch measurements reflected more time spent on the computer than the chart ( 4.4 minutes vs 2.8 minutes, $P \leq .002$ ), patients expressed satisfaction about physicians' eye contact and quality of visit.

\section{Patients' Views}

Patients now exhibited full acceptance of the EHR (Table 4) and lauded security, access to information, efficiency, information sharing, and the "modern" way of life. An 83-year-old man believed the EHR was confidential and secure: "...they must have a system maybe to protect all the information." Another approved, "Like all you do is click click click, and I'll have my labs." One preferred the computer because, "It ... never forgets like people do, and paper can get lost." A woman said, "I really got to see better on the computer than when they write it because it's very hard to understand." Another approved that the physician looked up laboratory results on the computer. A 65 -year-old man noted, "Paperwork is out of style," whereas a 56-year-old woman declared, "I trust [the physician]....anything I need to know she tells me about me."

Patients expressed ambivalence about computer security, however. A woman said, "I just don't want my medical records being opened up on the computer for the world to see..." and noted anxieties about hacking. Although a 29-year-old woman said the EHR was, "OK as long as no one breaks in...," another voiced a not-infrequent opinion: "Anybody could get to those records. The point is, I don't particularly care."

Staff focus group reactions, noted in Table 5, were frequently enthusiastic, echoing nursing station remarks ("I love the computer!"). They applauded efficient workflow ("I personally think it's wonderful," "Nobody is looking for charts"). Some said they believed the physicians' notes were more accurate; the EHR speeded referrals and legal correspondence ("You just print it up...fax it, send it, whatever"); and new templates allowed faster physician input. A nurse appreciated the incentive for physicians to complete EHR input: "If you don't... finish your chart, I cannot update your med list, and hello, I can't help you." One considered that, "... having our patients being curious about what's in their chart and what's going on about them...makes...them responsible."

\section{Overall Physician Adaptation Strategies}

Physicians adapted to the EHR use by body position, computer placement, verbal references to the com- puter, and how they shared information with patients. Physicians appeared to try to decrease computer intrusiveness. The computer could still create unpleasant surprises, such as delayed log-ins, frozen screens, and computer crashes. Physicians made explicit computer references, sometimes apologizing for computer awkwardness (eg, "If this could go any slower...," or "Oww, what'd I do? ... I always spell it wrong!").

During the transition, physicians would commonly sit facing the patient with the chart on their lap, stand to examine the patient, then sit to discuss findings. With implementation, physicians increasingly turned the computer monitor so the patient could view it more easily and alternated looking at the computer screen with maintaining patient eye contact. As the researcher wrote,

Physician at computer...talks to patient and asks...turns his head...toward patient...to talk.... He types and asks questions, [saying]: "I've just got to write this down."

Nonverbal strategies were now frequent. One physician, with an immovable keyboard and monitor before him, stretched his arm back toward the patient on the examination table, creating a symbolic link with the patient he could not directly face. Others extended a leg or angled knees toward the patient sitting beside the computer. When the patient was on the examination table, the physicians' knees were often awkwardly perpendicular to the patient while the physician's body faced the computer with back to the patient.

After implementation, physicians appeared more relaxed. The researcher's notes read:

Physician...says, "Hi, sorry for the wait, " and goes to computer...says, "Bear with me for a minute for this nonsense...." She turns the screen toward the patient and has the patient pull her chair closer. She looks at the screen while typing, pauses, looks at the patient while she talks.

Some physicians repeated aloud what they read or wrote in the EHR; this activity slowed the patient's narrative and allowed time to type and scroll through the record. "Let me just bring up your screen," and "If the computer will let me do this...," were common utterances. One physician delighted a young patient by pointing to icons on the screen, asking, "Would you like fries with that?"

\section{Sharing Chart Information}

Initially, sharing paper chart information was verbal while the chart remained out of the patient's visual range. Although during the transition physicians rarely shared patient information on the computer, they often shared information on the screen after the implementation. The researcher's notes read: "Physician...calls 
patient to the screen and shows her the labs...uses the cursor to direct the patient [saying], 'Don't look at me, look at this_-the lab results."' At study's end the researcher witnessed a physician sharing the paper chart with the patient.

\section{DISCUSSION}

As EHRs became integrated in this setting, concerns about deleterious consequences of EHR implementation were ameliorated, positive outcomes were realized, and unexpected benefits were revealed.

\section{Increased Comfort With the Third Actor}

The choice of where in the room the computer is placed $^{28}$ and its role as a third actor ${ }^{17}$ alters the physician-patient interaction in a major way. ${ }^{22-24,27,35} \mathrm{We}$ document how initially awkward physicians increased in confidence with time and became more adept. As others have noted, physicians accommodated through body language, introductions to the EHR, excuses for computer set-up delay, monitor positioning for collaborative viewing, invitations for patients to sit closer, and references to the computer as a shared burden. ${ }^{18,38}$ Repeating patients' words while typing signaled physician attention and allowed time for correction by this "pausing." 39 Just-in-time information and referrals added to efficient work flows and accompanied increased sharing of the EHR with the patient ${ }^{25}$ in contrast to the physicians' not sharing the paper chart before EHR implementation. Though EHR multitasking may be burdensome, ${ }^{8,22}$ adjustment was noteworthy because so few physicians were early EHR adopters. This adaptation supports recommendations for preparatory discussion and gradual implementation. . $^{150}$

\section{Trust in the Physician Relationship}

Trust in the physician and the security of the therapeutic relationship appeared to override most patients' concerns. Patients generally acknowledged exigencies of the physician's job and expressed appreciation of less wasted time and fewer physician exits. ${ }^{12,25}$ Although patients were ambivalent about EHR security, many noted their accommodation to the benefits and anxieties of the 21st-century electronic-age reality that no system is ultimately foolproof. Although the literature asserts decreased patient-centeredness with EHR use, $8,16,20,23,27,35$ and clinical staff expressed concern about eye contact, ${ }_{1}^{16,41}$ these patients seemed to assume patient-centeredness in EHR use by interpreting the focus on documentation as evidence of physicians' caring, ${ }^{36}$ and they reported no less satisfaction with the relationship. ${ }^{12,42}$ Such a positive relationship may provide the foundation to enhance patient health care responsibility ${ }^{3,37}$ as clinical information shifts from physician to joint control.

\section{Limitations}

Participating patients may have been more satisfied with their physicians than those who declined participation. Conducting exit interviews within the clinic (albeit in private rooms) may have inhibited patient criticism. Although anthropological observation contains some subjective aspects, the use of one researcher and a standard observation form and interview guide provided a uniform record to increase rigor. Extensive discussions by the analysis team facilitated consideration of alternate interpretations of findings.

\section{Implications for Theory and Practice}

EHRs in health care settings pose challenges to medical practice. Clinical staff must learn the system and coordinate efforts. ${ }^{15}$ EHR mechanics can be overwhelming, but they are ultimately surmountable. ${ }^{38}$ Curricula for EHR training are clearly necessary. In addition, physicians should learn to type well before moving to the $\mathrm{EHR}^{17}$ and be trained to improve communication. ${ }^{39}$ Computer placement in the consultation room should be considered, as it affects the patient inclusivity ${ }^{28}$ or openness ${ }^{39}$ during the physician-patient interaction. Further study should focus on how the patient record is shared, increased patient access to the patient record may lead to decreased physician authority, yet it may also enhance the physician-patient partnership and patient responsibility. ${ }^{37}$ Further outcomes research may also be warranted to examine the effects of EHR use on health and disease. In this population, our results justified the considerable expense, time, and effort expended. It is highly plausible that similar results could be obtained in comparable settings.

To read or post commentaries in response to this article, see it online at http://www.annfammed.org/cgi/content/full/8/4/316.

Key words: Electronic health record; physician-patient relations; patient satisfaction

Submitted May 20, 2009; submitted, revised, December 18, 2009; accepted December 28, 2009.

Funding support: This research was supported by an Academic Administration Units grant from the Health Resources and Services Association, grant No. D54HP00121.

Portions of the manuscript content were presented at the North American Primary Care Research Group (NAPCRG) Annual Meeting, Quebec City, Canada, October 2005, and at the NAPCRG Annual Meeting, Tucson, Arizona, October 2006.

Acknowledgments: The authors wish to thank the patients, physicians, nurses, and other staff of the Family Care Center at Memorial Hospital 
of RI who generously agreed to participate in this research. We also acknowledge the helpful administrative support of Irene Reis and Pedro Pichardo's assistance in the preparation of tables.

\section{References}

1. Blumenthal D, Glaser JP. Information technology comes to medicine. New Engl J Med. 2007;356(24):2527-2534.

2. Sullivan F, Wyatt JC. How computers help make efficient use of consultations. BMJ. 2005a;331(7523):1010-1012.

3. Sullivan F, Wyatt JC. How computers can help to share understanding with patients. BMJ. 2005b;331(7521):892-894.

4. Hersh WR. Medical informatics: improving health care through information. JAMA. 2002;288(16):1955-1958.

5. Ferreira A, Correia A, Silva A, et al. Why facilitate patient access to medical records. Stud Health Technol Inform. 2007;127:77-90.

6. Weber V, White A, Mcllvried R. An electronic medical record (EMR)based intervention to reduce polypharmacy and falls in an ambulatory rural elderly population. J Gen Intern Med. 2008;23(4):399-404.

7. Arar NH, Wen L, McGrath J, Steinbach R, Pugh JA. Communicating about medications during primary care outpatient visits: the role of electronic medical records. Inform Prim Care. 2005;13(1):13-22.

8. Shachak A, Reis $S$. The impact of electronic medical records on patient-doctor communication during consultation: a narrative literature review. J Eval Clin Pract. 2009;15(4):641-649.

9. Hippisley-Cox J, Pringle M, Cater R, et al. The electronic patient record in primary care-regression or progression? A cross sectional study. BMJ. 2003;326(7404):1439-1443.

10. Sullivan F, Wyatt JC. How informatics tools help deal with patients' problems. BMJ. 2005c;331(7522):955-957.

11. Mador RL, Shaw NT, Cheetham S, Reid RJ. Whose record is it anyway? Putting patients' interests at the heart of the implementation and use of electronic medical records. Healthc Q. 2008;11(4):90-92.

12. Hsu J, Huang J, Fung V, Robertson N, Jimison H, Frankel R. Health information technology and physician-patient interactions: impact of computers on communication during outpatient primary care visits. J Am Med Inform Assoc. 2005;12(4):474-480.

13. Lohr S. Most physicians aren't using electronic health records. New York Times. June 19, 2008.

14. Ludwick DA and Doucette J. Primary care physicians' experience with electronic medical records: barriers to implementation in a fee-for-service environment. Int J Telemed Appl. 2009; ID 853524.

15. Crosson JC, Stroebel C, Scott JG, Stello B, Crabtree BF. Implementing an electronic medical record in a family medicine practice: communication, decision making, and conflict. Ann Fam Med. 2005; 3(4):307-311.

16. Margalit RS, Roter D, Dunevant MA, Larson $S$, Reis $S$. Electronic medical record use and physician-patient communication: an observational study of Israeli primary care encounters. Patient Educ Couns. 2006;61(1):134-141.

17. Ventres W, Kooienga S, Vuckovic N, Marlin R, Nygren P, Stewart V. Physicians, patients, and the electronic health record: an ethnographic analysis. Ann Fam Med. 2006:4(2):124-131.

18. Frankel R, Altschuler A, George $S$, et al. Effects of exam-room com puting on clinician-patient communication: a longitudinal qualitative study. J Gen Intern Med. 2005;20(8):677-682.

19. Gibson M, Jenkings KN, Wilson R, Purves I. Multi-tasking in practice: coordinated activities in the computer supported doctorpatient consultation. Int J Med Inform. 2005;74(6):425-436.

20. Armstrong-Cohen A. The computer will see you now. New York Times. March 6, 2009.

21. Patel VL, Kushniruk AW, Yang S, Yale JF. Impact of a computerbased patient record system on data collection, knowledge organization, and reasoning. J Am Med Inform Assoc. 2000;7(6):569-585.
22. Booth N, Robinson P, Kohannejad J. Identification of high-quality consultation practice in primary care: the effects of computer use on doctor-patient rapport. Inform Prim Care. 2004;12(2):75-83.

23. Patel VL, Arocha JF, Kushniruk AW. Patients' and physicians' understanding of health and biomedical concepts: relationship to the design of EMR systems. J Biomed Inform. 2002;35(1):8-16.

24. Als AB. The desk-top computer as a magic box: patterns of behaviour connected with the desk-top computer; GPs' and patients' perceptions. Fam Pract. 1997;14(1):17-23.

25. Makoul G, Curry RH, Tang PC. The use of electronic medical records: communication patterns in outpatient encounters. J Am Med Inform Assoc. 2001;8(6):610-615.

26. Sequist TD, Cullen T, Hays H, Taualii MM, Simon SR, Bates DW. Implementation and use of an electronic health record within the Indian Health Service. J Am Med Inform Assoc. 2007;14(2):191-197.

27. Rouf E, Whittle J, Lu N, Schwartz MD. Computers in the exam room: differences in physician-patient interaction may be due to physician experience. J Gen Intern Med. 2007;22(1):43-48.

28. Pearce C, Walker H, O'Shea C. A visual study of computers on doctors' desks. Inform Prim Care. 2008;16(2):111-117.

29. Keshavjee K, Manji A, Singh B, Pairaudeau N. Failure of electronic medical records in Canada: A failure of policy or a failure of technology? In: McDaniel JG, ed. Studies in Health Technology and Informatics; Advances in Information Technology and Communication in Health. 2009; Vol. 143.

30. Al-Azmi SF, Al-Enezi N, Chowdhury RI. Users' attitudes to an electronic medical record system and its correlates: A multivariate analysis. HIM J. 2009;38(2):33-40.

31. Creswell JW, Fetters MD, Ivankova NV. Designing a mixed methods study in primary care. Ann Fam Med. 2004;2(1):7-12.

32. Crabtree BF, Miller WL, eds. Doing Qualitative Research. 2nd ed. Thousand Oaks, CA: Sage Publications; 1999.

33. Borkan J. Immersion/crystallization. In: Crabtree BF, Miller WL, eds, Doing Qualitative Research. 2nd ed. Thousand Oaks, CA: Sage Publications; 1999: 179-194.

34. Curry L, Shield R, Wetle T, eds. Improving Aging and Public Health Research: Qualitative and Mixed Methods. Washington, DC: American Public Health Association and The Gerontological Society of America; 2006.

35. Pearce C, Trumble S. Computers can't listen-algorithmic logic meets patient centredness. Aust Fam Physician. 2006;35(6):439-442.

36. Scott JG, Cohen D, Dicicco-Bloom B, Miller WL, Stange KC, Crabtree BF. Understanding healing relationships in primary care. Ann Fam Med. 2008;6(4):315-322.

37. Walker J, Ahern DK, Le LX, Delbanco T. Insights for internists: "I want the computer to know who I am". J Gen Intern Med. 2009; 24(6):727-732.

38. Pearce C, Dwan K, Arnold M, Phillips C, Trumble S. Doctor, patient and computer-a framework for the new consultation. Int J Med Inform. 2009;78(1):32-38.

39. McGrath JM, Arar NH, Pugh JA. The influence of electronic medical record usage on nonverbal communication in the medical interview. Health Informatics J. 2007;13(2):105-118.

40. Nemeth LS, Feifer C, Stuart GW, Ornstein SM. Implementing change in primary care practices using electronic medical records: a conceptual framework. Implement Sci. 2008;3:3.

41. Aydin CE, Forsythe DE. Implementing computers in ambulatory care: implications of physician practice patterns for system design. Proc AMIA Annu Fall Symp. 1997:677-81.

42. Solomon GL, Dechter M. Are patients pleased with computer use in the examination room? J Fam Pract. 1995;41(3):241-244. 